\title{
Authoritarian Dimension of Judicial Ideology of the Slovenian Constitutional Court
}

\author{
Jernej Letnar Černic* \\ https://doi.org/10.31297/hkju.20.4.6 \\ UDK 342.565.2:321.64(497.4) \\ $342.72 / .73(497.4)$ \\ 342.392(497.4) \\ Original scientific paper / izvorni znanstveni rad \\ Received / primljeno: $\quad$ 10. 6. 2020. \\ Accepted / prihvaćeno: $\quad 30.10 .2020$.
}

This article discusses and analyses the authoritarian dimension of judicial ideology of the Slovenian Constitutional Court. It is based on the empirical research measuring the presence of judicial ideology at the Constitutional Court of Slovenia in the selected periods of 1993-1997, 2002-2006, and 2011-2016 within the first three eight-year mandates. The article examines how authoritarian the Slovenian Constitutional Court has been in its judicial decision-making during the mentioned years. Our research illustrates that all three mandates of the Slovenian Constitutional Court show a preference for a central ideological position with respect to the authoritarian dimension of judicial ideology and cannot therefore be described as authoritarian in their decision-making.

* Jernej Letnar Černič, Associate Professor, Faculty of Government and European Studies, New University, Kranj, Slovenia (izvanredni profesor Fakulteta za državne i europske studije, Novo sveučilište u Kranju, Slovenija, e-mail: jernej.letnar@gmail.com).

ORCID ID: https://orcid.org/0000-0001-6850-676X 
Keywords: judicial ideology, Slovenian Constitutional Court, the rule of law, constitutional democracy, human rights

\section{Introduction ${ }^{1}$}

Fair trial guarantees are the backbone of constitutional democracies and the rule of law. Judges of ordinary courts and constitutional courts are tasked with safeguarding those guarantees in the domestic systems. As a rule, the strength and quality of democratic institutions and the rule of law in constitutional democracies depends on the people. The right to a fair trial in the judiciaries depends on the people who exercise the judicial functions. As a result, safeguarding the right to an impartial and independent tribunal as a part of fair trial guarantees is to be particularly defended in constitutional democracies. Judges are human beings who do not decide cases technically as robots would do artificially (Garoupa, 2010). They are influenced by the ideology, which is the result of their family, private and professional lives and relationships (Letnar Černič, 12. 7. 2019). Those factors influence their judicial decision-making (ibid). As such, every judge shapes their decision-making according to their own judicial ideology. Ideology is therefore a seminal factor in judicial decision-making.

The Slovenian legal system is an example of the post-socialist legal system (Uzelac, 2010). The Slovenian professional associations of judges have often argued that they decide cases objectively and are ideologically neutral, thereby explaining that they do not allow interference by any external pressures (Letnar Černič, 12. 7. 2019). Nonetheless, an objectivist understanding of the application of law does not accurately explain the daily realities of the judicial profession (ibid). Every judge has, in her decision-making, been influenced by various factors from their private, family, and professional lives (ibid). Only a robot judge could, perhaps through artificial intelligence, decide cases in an ideologically neutral way (Kleinberg et al., 2018).

1 This article has been written under the auspices of the research project Ideology at Courts: The Influence of Judges' World-views on Their Decisions, Slovenian Research Agency (2017-2021), J5-8240 (A) and the research project Holistic Approach to Business and Human Rights: A Normative Reform of Slovenian and International Legal Order, Slovenian Research Agency (2019-2022, no. JP-1790). 
The private, family, and professional lives of judges have often been decisive in reaching decisions in judicial disputes (Letnar Černič, 12. 7. 2019). They explain whether a particular judge will favour to protect the authority and stability of the legal order or individual rights, whether they will favour the rights of the majority or those of the minorities, or whether they will protect the free market or state interests (Avbelj \& Šušteršič, 2019, pp. 143-144). For these reasons, Slovenian judges, as other judges, are primarily social beings who are an integral part of the Slovenian society, with all its strengths and weaknesses (ibid). That is why the discursive conception of law more accurately describes features of judicial decision-making.

Judicial ideology has been well researched in the United States (Cross \& Tiller, 1998), but less so in Europe, particularly in Central and Eastern Europe, where it has often been contended that judges decide cases neutrally. Researchers have only recently attempted to measure judicial ideology at the highest courts in Central and Eastern Europe (Hanretty, 2014; Kantorowicz \& Garoupa, 2016; Avbelj, 2019; Avbelj et al., 2018; Szente, 2016; Pócza, Dobos \& Gyulai, 2019; Pócza, Dobos \& Gyulai, 2017). This article attempts to fill this gap by concentrating on the measurement of the authoritarian dimension of judicial ideology of the Slovenian Constitutional Court.

The Slovenian system has, like many continental systems, followed the objectivist conception of the law, which derives its legal authority from the legal form and procedure where the norm was developed (Letnar Černič, 12. 7. 2019; Zobec \& Letnar Černič, 2015). The ordinary judiciary in Slovenia has been, since independence and democratization, vastly formed by the objectivist conception of law. For instance, most of the judgements of the ordinary courts are not published, i.e. publicly available (Avbelj \& Letnar Černič, 2020). As a result, some commentators have argued that the ordinary courts have been known to follow formalistic, positivistic, and authoritarian judicial decision-making (Avbelj, 2019; Zobec, 2015).

In contrast, the Constitutional Court of Slovenia has been known for the transparency of its functioning. Moreover, it has been known for its discursive approach to law, which emphasizes the importance of legal argumentation. As a rule, its decisions and separate opinions are more likely to be scrutinized and discussed among the professional and wider audiences. Hence, the decisions of the Constitutional Court are more open to the measurement of the presence of judicial ideology. The Constitutional Court of Slovenia has, after democratization and independence, generat- 
ed a paradigm shift in the Slovenian constitutional system by protecting individual rights against the heritage of the former authoritarian system (Avbelj \& Letnar Černič, 2020; Letnar Černič, 2018a; Letnar Černič et al., 2018; Letnar Černič, 2018b; Letnar Černič, 2018a; Avbelj, 2018a; Avbelj, 2018b).

The judges at the Slovenian Constitutional Court are elected by a simple majority by the National Assembly on the proposal of the President of the Republic (Constitution of the Republic of Slovenia, Art. 163 (1)). The Slovenian Constitutional Court publishes its decisions and separate opinions, thereby enabling measurement of their judicial ideology. Traditionally, most of the judges of the Slovenian Constitutional Court have been fond of and have seized the opportunity to write concurring and dissenting separate opinions in order to present arguments for or against the majority decision (ibid). As a result, the Slovenian Constitutional Court is a textbook example for the study, measurement and assessment of judicial ideology. However, not much has been published so far on the ideology of the Slovenian Constitutional Court (Avbelj et al., 2018).

The Constitutional Court of Slovenia has, in the past three decades, delivered several seminal decisions concerning the protection of the rule of law, human rights and constitutional democracy. However, not much, if anything, has been published as to the reasons and judicial ideology that were used to structure those judgements. This article is based on the empirical research that measured the presence of judicial ideology at the Constitutional Court of Slovenia during three mandates (1993-1997, 2002-2006, and 2011-2016) (ibid.). It measures the economic, social, and authoritarian dimensions of judicial ideology (a three-fold judicial ideology model) (Letnar Černič, 22. 3. 2019). What triggers constitutional judges to protect individual rights in some cases and in others to show preference for the preservation of the authority and stability of the existing legal system? More specifically, the main research question of this article is how authoritarian has the Slovenian Constitutional Court been in its judicial decision-making during the analysed periods. The objective is to present the results obtained from measuring the ideological profiles of the Court and its individual judges relating to the authoritarian dimension of judicial ideology. These empirical results will help the research group to develop guidelines for improving judicial-making at the Constitutional Court based on the values of the rule of law, constitutional democracy, and human dignity in order to ensure the impartial and independent functioning of the judicial system and individual judges. 


\section{Methodology}

This research is based on a previously developed multidimensional methodological approach that enables the measurement of judicial ideology in the Slovenian Constitutional Court (Avbelj \& Šušteršič, 2019). The methodological approach that has been employed is perhaps unconventional, as the majority of the literature on judicial ideology employs the one-dimensional approach (Bailey, 2016). Nonetheless, judicial decision-making is affected by various values, opinions and beliefs, thereby requiring a multidimensional approach to measuring judicial ideology. In order to accurately measure judicial ideology at the Slovenian Constitutional Court, we measured three different dimensions of judicial ideology (Avbelj et al., 2018; Avbelj 2019; Avbelj \& Šušteršič, 2019). The multi-dimensional model was divided into an economic, social, and authoritarian dimension of judicial ideology. In this way, we measured different aspects and nuances of the decision-making at the Slovenian Constitutional Court in order to obtain a complete picture of its judicial ideology. We examined and coded the decisions of five selected years during the first three mandates of the Constitutional Court (1993-1997, during the first mandate, 2002-2006, during the second mandate, and 2011-2016, during the third mandate). We concentrated on those three periods as the composition of the Constitutional Court in those periods remained more or less the same. As a result, we were able to thoroughly examine the decisions of the same compositions of all three mandates and reach more persuasive conclusions.

Subsequently, for each year we selected about twenty of the most important decisions from all three mandates. The decisions were chosen based on their importance, as they were identified in the annual reports of the Constitutional Court, as well as other criteria. More specifically, Avbelj and Šušteršič noted that the decisions were chosen on the basis of the following criteria: "decisions that the Court itself has declared as important in its annual reports"; "decisions not taken unanimously, or with concurring or dissenting separate opinions"; "decisions on important legal and social issues that relate to our definition of the three ideological dimensions"; "decisions of a precedential character or with important social consequences"; and "decisions related to highly controversial issues in the political and public discussions" (Avbelj \& Šušteršič, 2019, p. 148). We have thus examined, coded, and assessed 336 decisions of the Slovenian Constitutional Court. After the selection, we first identified whether the decisions included economic, social, and authoritarian dimensions of judicial ideology. Each de- 
cision does not contain all dimensions, however all of them include at least one. Data was thereafter generated for each of the dimensions. We then proceeded to hand-code each decision in the range of 1 to 5; from one to the other side of the ideological spectrum. Equally, the ideological position of potential counter-decisions was also hand-coded. We employed a multi-stage peer review process in order to ensure quality control and adequacy of each ideological position given to each of the decisions. The ideological position for each of the selected decisions was hand-coded by a member of the research team, who thereafter sent their assessment to another member of the research team (Avbelj et al., 2018). As a rule, all assessments were subjected to a rigorous and diligent peer-review process. In the case of disagreements between the author of a report on a particular decision of the Constitutional Court and the peer reviewer, the draft was discussed at the regular meetings of the research group (Avbelj \& Šušteršič, 2019, pp. 143144). All the researchers would read the draft report and dissenting opinion of the relevant reviewer, and the final positions were voted on among all the researchers, and in most cases adopted unanimously. In this way, we have attempted to eliminate bias(es) of individual reviewers.

For the purpose of this article, we will only present and analyse the results pertaining to the authoritarian dimension of judicial ideology, as it is primarily connected to the research question (Avbelj et al., 2018). The authoritarian dimension, as Table 1 explains in detail below, measures whether a judge is more inclined to protect the human rights of individuals (position 1), or favours the protection of state interests (position 5) (Avbelj \& Šušteršič, 2019, pp. 143-144). To be clear, we have distinguished between the authoritarian and social dimension of judicial ideology. Whereas the authoritarian dimension measures the relationship between individual rights and the authority and stability of the legal system, the social dimension studies the relationship between the individual or minority interests and the majoritarian interests and rights of the majority. The middle position (3) signifies a position that attempts to reconcile individual rights with the interests of the state and society at large (ibid). The authoritarian dimension measures the respect of individual rights in the vertical relationship between the individual and the state and its legal system. Position 1 is traditionally associated with the left and position 5 with the right ideological positions, whereas position 3 represents a middle position between individual and state interests. For instance, a decision on freedom of expression has been placed in position 1 or 2 if it protected the individual free speech against unjustified state intervention. On the contrary, the decision would have been placed in position 4 or 5 
if it had favoured state intervention and showed preference for the preservation of the existing legal order. Moreover, positions 1 and 5 signify a strong ideological position, whereas positions 2, 3 and 4 portray moderate ideological positions (ibid, p. 145). Those positions are more clearly explained in Table 1 below.

Table 1. Explanation of the ideological positions of the authoritarian ideological dimension

\begin{tabular}{|c|c|}
\hline $\begin{array}{l}\text { Ideologi- } \\
\text { cal posi- } \\
\text { tion }\end{array}$ & Authoritarian ideological dimension \\
\hline 1 & $\begin{array}{l}\text { Protection of individual rights against (arbitrary) interference by the state. } \\
\text { Human rights and fundamental freedoms enjoy preference over state in- } \\
\text { terference. The authoritarian dimension includes protection of both abso- } \\
\text { lute and relative rights. The state does not have discretion to limit absolute } \\
\text { rights, such as the right to life, prohibition of torture and prohibition of } \\
\text { forced and slave labour. Individual rights have priority over the stability } \\
\text { and authority of public order. }\end{array}$ \\
\hline 2 & $\begin{array}{l}\text { Human rights are important for the functioning of the society, however, } \\
\text { they can be interfered with under justified reasons, such as the protection } \\
\text { of public safety, public order or public health among others. Individual } \\
\text { rights can be interfered with if justified and necessary in a democratic } \\
\text { society. This position is closer to the protection of individual freedom and } \\
\text { liberty than to the protection of state interests. }\end{array}$ \\
\hline 3 & $\begin{array}{l}\text { This position attempts to find a reasonable balance between individual } \\
\text { rights and the authority and stability of state order and respect for the } \\
\text { rules. All decisions should be delivered on the basis of the principle of } \\
\text { proportionality. Both the values, individual rights and the preservation of } \\
\text { state interests are essential for the functioning of the society, however, the } \\
\text { stability of the legal order should not be underestimated in a democratic } \\
\text { society. }\end{array}$ \\
\hline 4 & $\begin{array}{l}\text { The stability and authority of the state, its interests and its legal order } \\
\text { has, in general, priority over the protection of individual rights. Individual } \\
\text { rights have to be protected in the light of general interests of the state. } \\
\text { As a result, this ideological point presents a position that is closer to the } \\
\text { protection of the authority and the stability of the state legal order and is } \\
\text { more distant from the freedom and liberty of individuals. }\end{array}$ \\
\hline 5 & $\begin{array}{l}\text { Stability and authority of the public order and the existing legal system } \\
\text { has preference over individual rights regardless of their nature. Individual } \\
\text { rights should take backseat to the benefit of state intervention and state } \\
\text { interests. Individuals are to strictly obey the rules of the existing system } \\
\text { and the authority of the state. }\end{array}$ \\
\hline
\end{tabular}

Source: Author. 
The ideological positions of an individual mandate of the Constitutional Court and of an individual judge have been calculated on the basis of the sum of the number of times the decisions have been placed in a particular position (Avbelj et al., 2018, p. 6). The relative frequencies have been calculated on the basis of this number and they indicate the intensity of preferences for each position (ibid). The ideal ideological points have been calculated as the weighted average of all positions (1-5) in all decisions (ibid).

Such a methodological approach has, after several years of research work, generated sets of empirical data that among others contribute to answering the main research question. It demonstrates to a large extent how the Slovenian Constitutional Court has operated and formed consensus or dissent. The empirical data quite clearly illustrate whether a particular mandate of the Constitutional Court has been more biased towards protecting individual rights or has preferred to protect the authority and stability of the existing legal order. As the next section shows, some mandates and judges have been more prejudiced towards defending governmental interests, while others have appeared to protect individual rights. As a result, the data also directly offers comparisons between different mandates and judges within a particular mandate concerning the authoritarian dimension of judicial ideologies. All in all, the research has produced very clear findings as to the judicial ideology of each of the first three mandates of the existence of the Slovenian Constitutional Court and its members, thereby providing a basis for future research, such as comparing the judicial ideology of the Constitutional Court to that of the political parties that elected the constitutional judges.

\section{Ideological Positions of the Slovenian Constitutional Court Concerning the Authoritarian Dimension of Judicial Ideology}

This section describes and explains the ideological profiles of all three mandates of the Slovenian Constitutional Court and its judges concerning the authoritarian dimension of judicial ideology. For each of the mandates, it first discusses the ideological profile and ideal points of the full mandate of the Constitutional Court. It then presents and analyses the ideological positions of a typical decision of the examined mandate. Thirdly, it presents the findings of the research of individual judges in 
the examined mandates of the Constitutional Court on both sides of the ideological spectrum, referring to those judges who have most explicitly protected individual rights or those who show greater preference for the protection of collective interests as protected in the legal system. The figures below illustrate, for each mandate of the Court, the ideological profile and ideal points of the Court concerning the authoritarian dimension.

\subsection{The First Mandate of the Constitutional Court (1993-1997)}

The first mandate of the Constitutional Court has sought a balance between the restoration of individual rights and the authority of the newly formed Slovenian state. Figure 1 illustrates that the ideal points of the most important decisions delivered by the Constitutional Court in the period 1993-1997 concerning the authoritarian dimension rest in position 2.7. This position shows that the first mandate was perhaps slightly more inclined to protect state interests and the stability of the newly formed legal system than individual rights and freedoms. However, it is still located close to the middle of the ideological position between the protection of individual rights and the preservation of authority and stability of the existing legal order. Nonetheless, Figure 1 demonstrates that the examined decisions of the 1993-1997 period of the Constitutional Court have been almost proportionally spread over all 5 ideological positions, with the highest number of decisions being located in positions 1 and 2, which favour the protection of individual rights.

In order to explain the coding of the decisions delivered in the period between 1993 and 1997, let us make our discussion more concrete and look at the coding for the authoritarian dimension of judicial ideology for one of the decisions of the first mandate. The Constitutional Court, in the decision U-I-304/96 concerning legislative referenda, was not convinced by the arguments of the National Assembly (Constitutional Court of Slovenia, U-I-304/96, 7 November 1996). It held that it would not be possible to hold a referendum and election on the same day, nor was it convinced by the argument that there would be a mix of elections and referendum on the same day, as well as election and pre-referendum campaigns (ibid). The Constitutional Court therefore found the third and fourth point of the Decree, calling a legislative referendum for the elections to the National Assembly, unconstitutional, since the Referendum and People's Initiative Act does not provide the power to postpone the referendum day (ibid). 
Figure 1: Ideological profile and ideal points of the Constitutional Court (1993-1997) concerning the authoritarian dimension

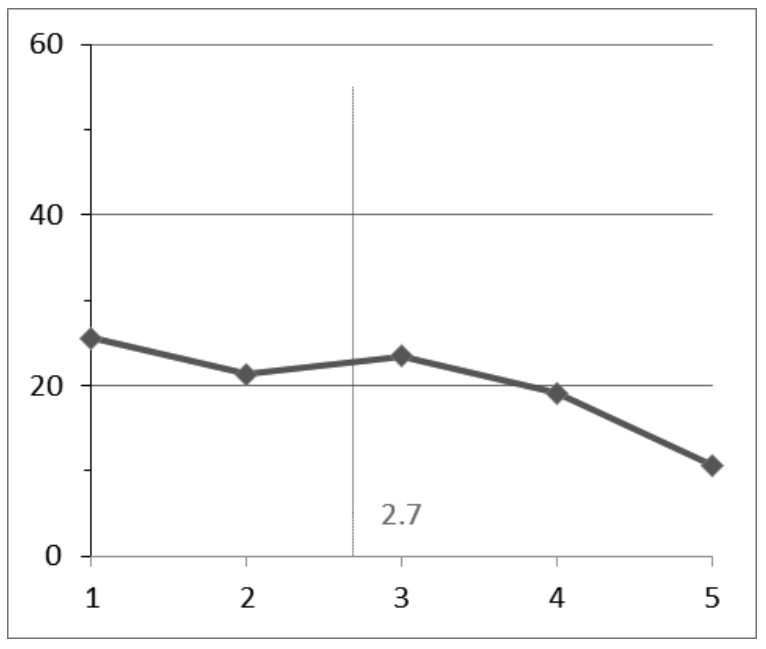

Source: Author. ${ }^{2}$

Explanation: The horizontal axis represents the ideological position, whereas the vertical axis illustrates the number of decisions/judgments for each position. The ideal ideological point is referenced by a red vertical line.

Table 2. Measurement of the authoritarian dimension of judicial ideology in the decision U-I-304/96 concerning legislative referenda

\begin{tabular}{|l|c|c|c|c|c|}
\hline AUTHORITARIAN DIMENSION & 1 & 2 & 3 & 4 & 5 \\
\hline Position of decision and counter-decision & & D & & CD \\
\hline $\begin{array}{l}\text { Position of Separate } \\
\text { Opinions }\end{array}$ & PDSO1 & $\begin{array}{c}\text { CSO1, } \\
\text { CSO2 }\end{array}$ & & $\begin{array}{c}\text { DSO1, } \\
\text { DSO2 }\end{array}$ \\
\hline CSO1 (Concurring Separate Opinion): Testen & & 2 & & & \\
\hline $\begin{array}{l}\text { CSO2 (Concurring Separate Opinion): } \\
\text { Jambrek }\end{array}$ & 2 & 2 & & \\
\hline $\begin{array}{l}\text { PDSO1 (Partially Dissenting Separate } \\
\text { Opinion): Jerovšek }\end{array}$ & & & \\
\hline
\end{tabular}

2 The author is grateful to Professor Janez Šušteršič for his contribution in the technical elaboration of the figures 1-15. 


\begin{tabular}{|l|l|l|l|l|l|}
\hline DSO1 (Dissenting Separate Opinion): Krivic & & & & & 2 \\
\hline $\begin{array}{l}\text { DSO2 Dissenting Separate Opinion: Ude, } \\
\text { Šinkovec }\end{array}$ & & & & & 2 \\
\hline Only against: / & & & & 1 & 1 \\
\hline Only for: Snoj, Šturm, Zupančič & 0,5 & 1 & 1 & & \\
\hline
\end{tabular}

Source: Author.

We have located the authoritative dimension in the relationship between the protection of the right of the petitioners to call a referendum and the government's own interference with it. The decision has a position 2 as the Constitutional Court found the illegality of the third and fourth points of the Decree on amendments to the call for a legislative referendum for elections to the National Assembly. However, it could not remedy its unlawful consequences. The decision therefore does not have position 1 as the Constitutional Court has only abstractly protected the right of the petitioners to call for the referendum. The Counter-Decision is located in position 5, as the Constitutional Court would have, in this case, completely rejected the petitioners' arguments about alleged interferences with their constitutional and legal rights, thus preserving the stability and authority of the legal order.

Judge Testen's Concurring Separate Opinion (CSO1) holds position 2, as his arguments are similar to those in the decision, i.e., that the contested points of the decree were found to be unlawful. Judge Jambrek's CSO2 is in position 2, arguing that the rights of the petitioners to call the referendum have been eroded, however he has not proposed concrete steps to enforce the illegality. Judge Jerovšek's PDSO holds position 1, suggesting that the Constitutional Court would only set a legal day to hold the referendum. In contrast, the Dissenting Separate Opinion (DSO1) of Judge Krivic holds position 5, favouring the authority and stability of the constitutional order over individual rights. At the same time, he did not find failure to comply with a previous decision of the Constitutional Court. Judge Ude's DSO2, joined by Judge Šinkovec, holds position 5, as the judge did not agree with the majority. He emphasized that there were substantiated reasons for the postponement of the referendum.

As Figure 2 illustrates, among the judges of the first mandate, Judge Jerovšek has scored the highest score on the ideological scale between political liberalism and individual rights, and state intervention. His position is to the left of the middle position between individual rights and state 
intervention. He has been closely followed by the voting patterns of Judge Šturm, as seen in Figure 3, who at the Constitutional Court engineered the normative break-up with the authoritarian system and its systematic human rights violations. On the other side of the spectrum, Figure 4 shows that judge Ude has favoured the protection of state interests against individual rights. His ideal ideological point is located in position 3.0, which is much closer to the protection of state interests than individual interests. Nonetheless, his voting pattern has not been far removed from the middle of the ideological positions. Similarly, Judge Snoj has also given preference to state intervention and the authority and stability of the existing legal system (Figure 5). The authoritarian dimension of the rest of the judges of that mandate is located between the positions of the ideological profiles of those judges.

Figure 2: Ideological profile and ideal points of Judge Jerovšek of the Constitutional Court (1993-1997) concerning the authoritarian dimension

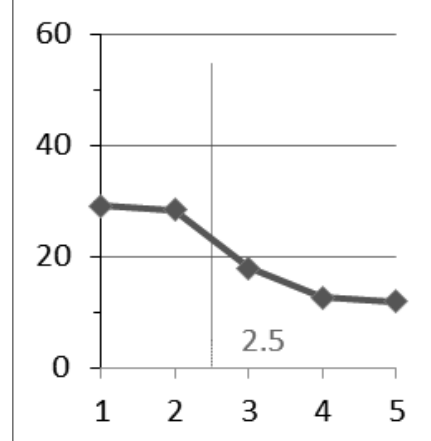

Figure 3: Ideological profile and ideal points of Judge Sturm of the Constitutional Court (1993-1997) concerning the authoritarian dimension

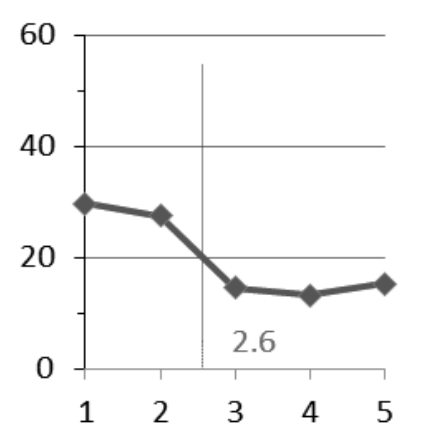




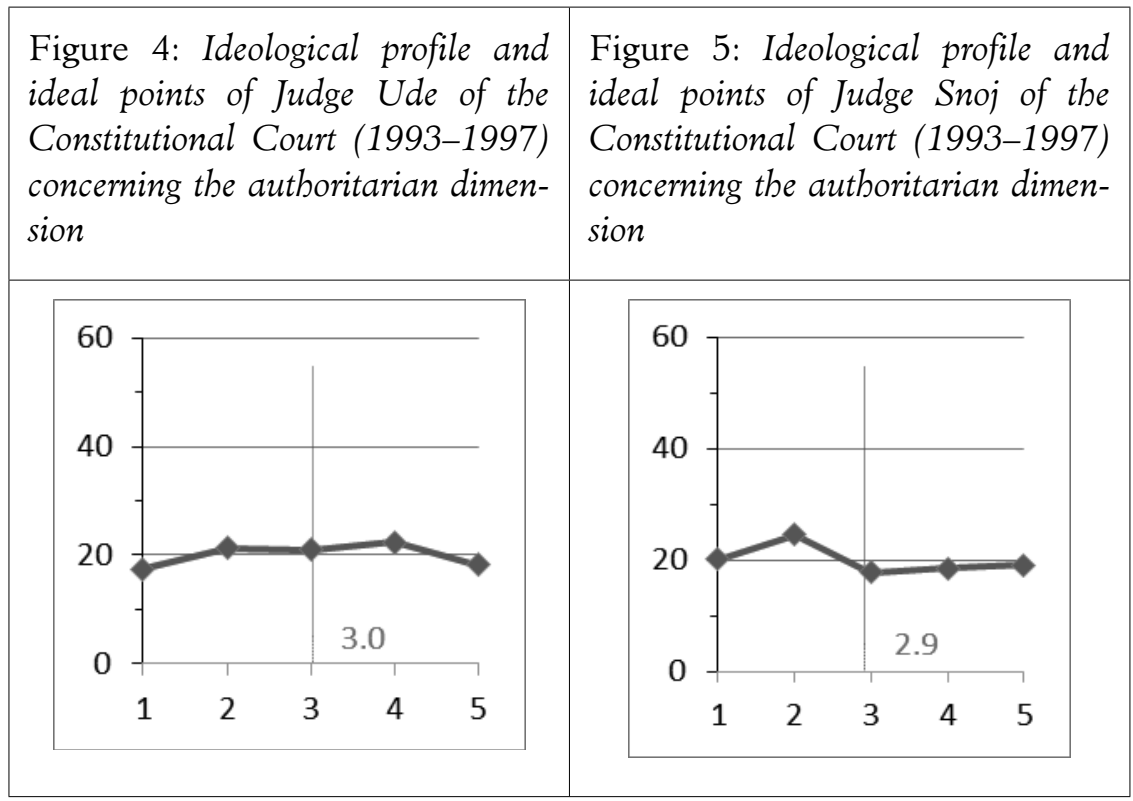

Source: Author.

\subsection{The Second Mandate of the Constitutional Court (2002-2006)}

The ideological profile and ideal points are slightly different for the second mandate of the Constitutional Court. Empirical research shows that the ideal points of the most important decisions delivered by the Constitutional Court in the period between 2002 and 2006 have even stronger preference for individual rights in relation to state intervention (with the ideological ideal in position 2.4). Most decisions are located in the ideological position 2 and very few in position 5 , as this position favours the stability of public order the most. The majority has shown greater preference for political rights than the authority and stability of the legal order. This is somehow surprising, as in the literature the second mandate of the Constitutional Court has not been known for protecting individual rights over state intervention, nonetheless the presence of some judges favouring individual rights may have turned the balance in favour of individual rights. 
Figure 6: Ideological profile and ideal points of the Constitutional Court (2002-2006) concerning the authoritarian dimension

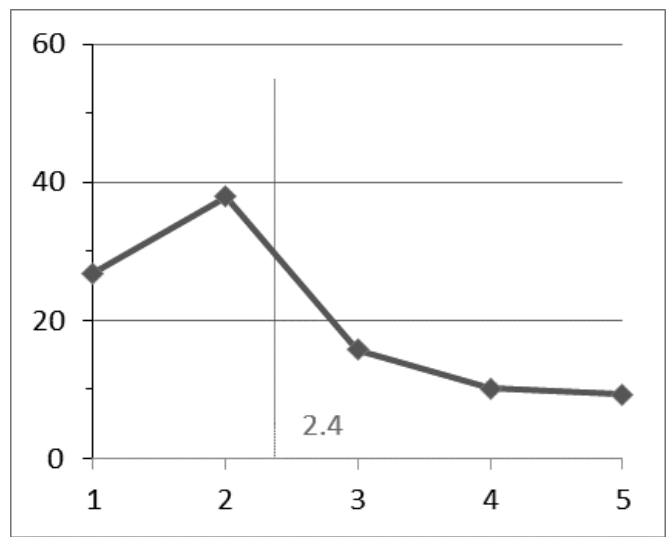

Source: Author.

Let us illustrate the authoritarian dimension of the second mandate by measuring the authoritarian dimension of judicial ideology in the decision U-I-246/02 concerning the "erased" (Constitutional Court of Slovenia, U-I-246/02, 7 April 2003). The Constitutional Court consensually decided that the Law regulating the status of citizens of other successor states of the former Yugoslavia in the Republic of Slovenia violates the Constitution, since the citizens of other republics of the former Yugoslavia were not recognized permanent residence as of 26 February 1992 (ibid). At the same time, it found that the same Act was unconstitutional as it did not regulate the acquisition of permanent residence for persons who had been forcefully removed under Article 28 of the Aliens Act (ibid).

Table 3. Measurement of the authoritarian dimension of judicial ideology in the decision U-I-246/02 concerning the "erased"

\begin{tabular}{|l|c|c|c|c|c|}
\hline Authoritarian dimension & 1 & 2 & 3 & 4 & 5 \\
\hline Position of decision (D) and counter-decision (CD) & D & & & & CD \\
\hline Position of Separate Opinion & & CS0 & & & \\
\hline Concurring Separate Opinion (CSO): Ribičič & & 2 & & & \\
\hline FOR: Everyone else & 1 & 1 & & 1 & 1 \\
\hline
\end{tabular}

Source: Author. 
The Constitutional Court prioritized the right to regulate the legal position of citizens of other successor states of the former Yugoslavia in the Republic of Slovenia. It protected their human dignity in relation to maintaining the stability and authority of the existing legal order. It found that the rights of citizens of other successor states of the former Yugoslavia in the Republic of Slovenia take precedence over the protection and stability of the existing legal order. The decision has position 1 , as the Constitutional Court ordered the National Assembly to remedy constitutional inconsistencies in the short term and also because of point 8 of the operative provision, which gives citizens from other successor states of the former Yugoslavia in the Republic of Slovenia the right to regulate their status already on the basis of this decision.

In his concurring separate opinion, Judge Ribičič argued that the Constitutional Court should have adopted an interpretative decision concerning the impugned provisions of the Act, as it does not regulate the acquisition of a permanent place of residence for persons under the Law regulating the status of citizens of other successor states of the former Yugoslavia in the Republic of Slovenia. His CSO has therefore position 2 notwithstanding the fact that the judge ultimately supported the decision of the majority, which found the unconstitutionality of the existing normative framework.

The counter-decision states that the Constitutional Court would have confirmed the legality of the law in force and would thus have given priority to the authoritative nature of the normative order, regardless of the potential controversy of the legal provisions. Therefore, it is located in position 5.

As Figures 7 and 8 show, Judges Wedam Lukić and Ribičič have been among the judges of the second mandate that have mostly favoured individual rights and political liberal rights (both of them in position 2.3). Both of them rarely voted for state interests and the preservation and stability of the legal order. Not surprisingly, only a few of their examined decisions have been ranked in the ideological position 5. Figure 7 shows that Judge Ribičičs's decisions have been predominantly located in the ideological positions 2 and 1, favouring individual rights. Similarly, Judge Wedam Lukić has, as seen from Figure 8 mostly voted in the ideological position 2. In contrast, the ideological profile and ideal points of Judge Krisper Kramberger are located in position 2.6, which illustrates that she has slightly favoured state interests and the stability of the legal order over individual rights. Moreover, one can find Judge Modrijan in the middle of the ideological positions (Figure 10). 
Figure 7: Ideological profile and ideal points of Judge Ribičič of the Constitutional Court (2002-2006) concerning the authoritarian dimension

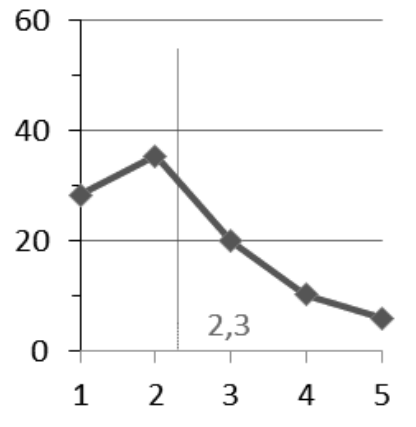

Figure 8: Ideological profile and ideal points of Judge Wedam Lukić of the Constitutional Court (2002-2006) concerning the authoritarian dimension

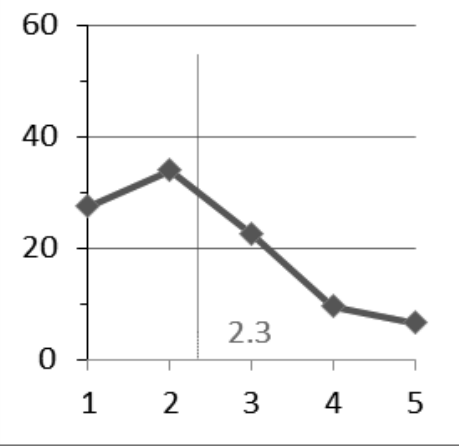

Figure 9: Ideological profile and ideal points of Judge Krisper Kramberger of the Constitutional Court (2002-2006) concerning the authoritarian dimension
Figure 10: Ideological profile and ideal points of Judge Modrijan of the Constitutional Court (2002-2006) concerning the authoritarian dimension
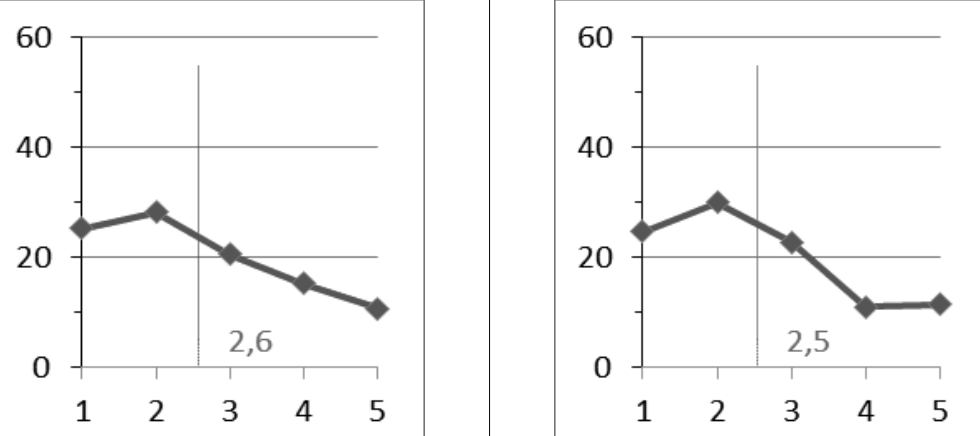

Source: Author. 


\subsection{The Third Mandate of the Constitutional Court (2011-2016)}

The ideological profile and ideal points of the third mandate of the Constitutional Court are located in position 2.0. Such a position illustrates that the third mandate favoured individual rights and political liberalism over the stability and authority of the legal order. It appears that the third mandate has shown slightly more preference towards the protection of individual rights than the first mandate. Such contestation rests also on the fact that the highest number of examined decisions were located in the ideological position 1 , followed by position 2 , whereas the lowest number of decisions are located in positions 3,4 , and 5 , which generally advance the stability of the legal order. Thus, the research reveals that the third mandate of the Constitutional Court has been located to the left of the centre of the possible ideological positions.

Figure 11: Ideological profile and ideal points of the Constitutional Court (2011-2016) concerning the authoritarian dimension

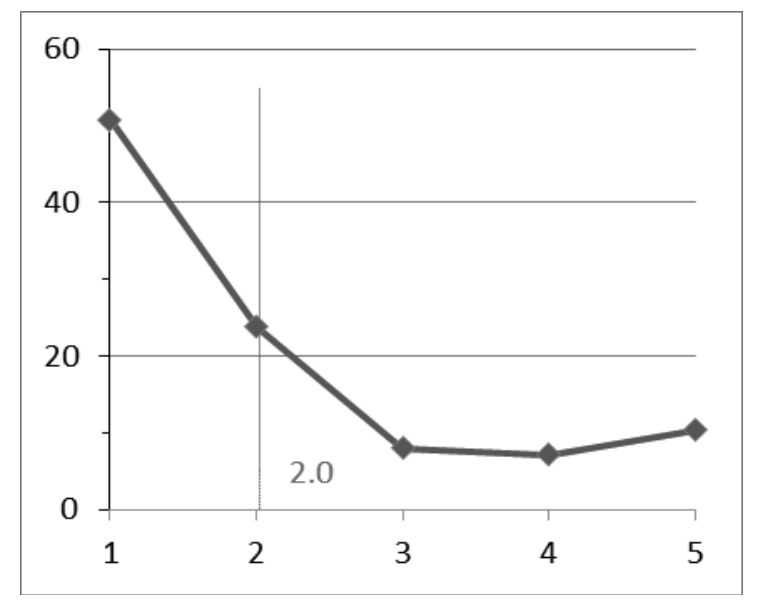

Source: Author.

Let us illustrate the authoritarian dimension of the third mandate by measuring the authoritarian dimension of judicial ideology in the decision Up-584/12 concerning freedom of expression (Constitutional Court of Slovenia, Up-584/12, 22 May 2014). The ordinary courts ordered the complainant to pay compensation for his offensive statements made on his television show Hribar and in interviews with various media (ibid). 
The Constitutional Court agreed with the complainant's arguments and reversed the judgment of the Higher Court and the Ljubljana District Court and remitted the case to the District Court for a re-examination (ibid). It explained that the ordinary courts had not sufficiently and adequately assessed the context of the case, especially in terms of how the statement was made and for whom it was intended, as well as the extent to which the appellant's freedom of artistic expression is protected in the case of value judgments (ibid).

Table 4. Measurement of the authoritarian dimension of judicial ideology in the decision Up-584/12 concerning freedom of expression

\begin{tabular}{|l|c|c|c|c|c|}
\hline Authoritorian dimension & 1 & 2 & 3 & 4 & 5 \\
\hline Position of decision and counter-decision & $\mathrm{D}$ & & & & $\mathrm{CD}$ \\
\hline FOR: Everyone else & 1 & 1 & & 1 & 1 \\
\hline
\end{tabular}

Source: Author.

In its decision, the Constitutional Court reversed the judgments of the ordinary courts as they did not adequately and sufficiently assess the context of the constitutional complaint, especially the extent of the protection of the complainant's freedom of artistic expression in the case of value judgments and other relevant issues. In doing so, it favoured the rights of the complainant to express himself artistically over the stability and authoritative nature of the legal system. Therefore, the decision is located in position 1. The Counter-decision has a position of 5, since the Constitutional Court would have completely rejected the complainant's arguments and would have favoured the authoritarian nature of the normative order, finding that there was no violation of the complainant's right to artistic and satirical expression.

As for individual judges of the third mandate, Judges Sovdat and Mozetič, as demonstrated by Figures 12 and 13, have most favoured individual rights and political rights (both in position 2.1), and rarely voted for state interests and the preservation and stability of the legal order. Not surprisingly, none of their examined decisions have been ranked in the ideological position 5, which mostly favours state interests. On the other hand, the ideological profile and ideal points of Judges Klampfer and Pogačar, as presented by figures 14 and 15, illustrate that they have favoured state interests and the stability of the legal order. For instance, 
figure 14 demonstrates that the highest score (2.8) in the preference for state intervention was found in the voting patterns of Judge Klampfer, who preferred state interference over the protection of individual rights in the majority of the decisions. Figure 15 illustrates that Judge Pogačar has been very close to the balance between the two ideological positions, thereby placing only a slight preference for stability and the preservation of the existing legal order.

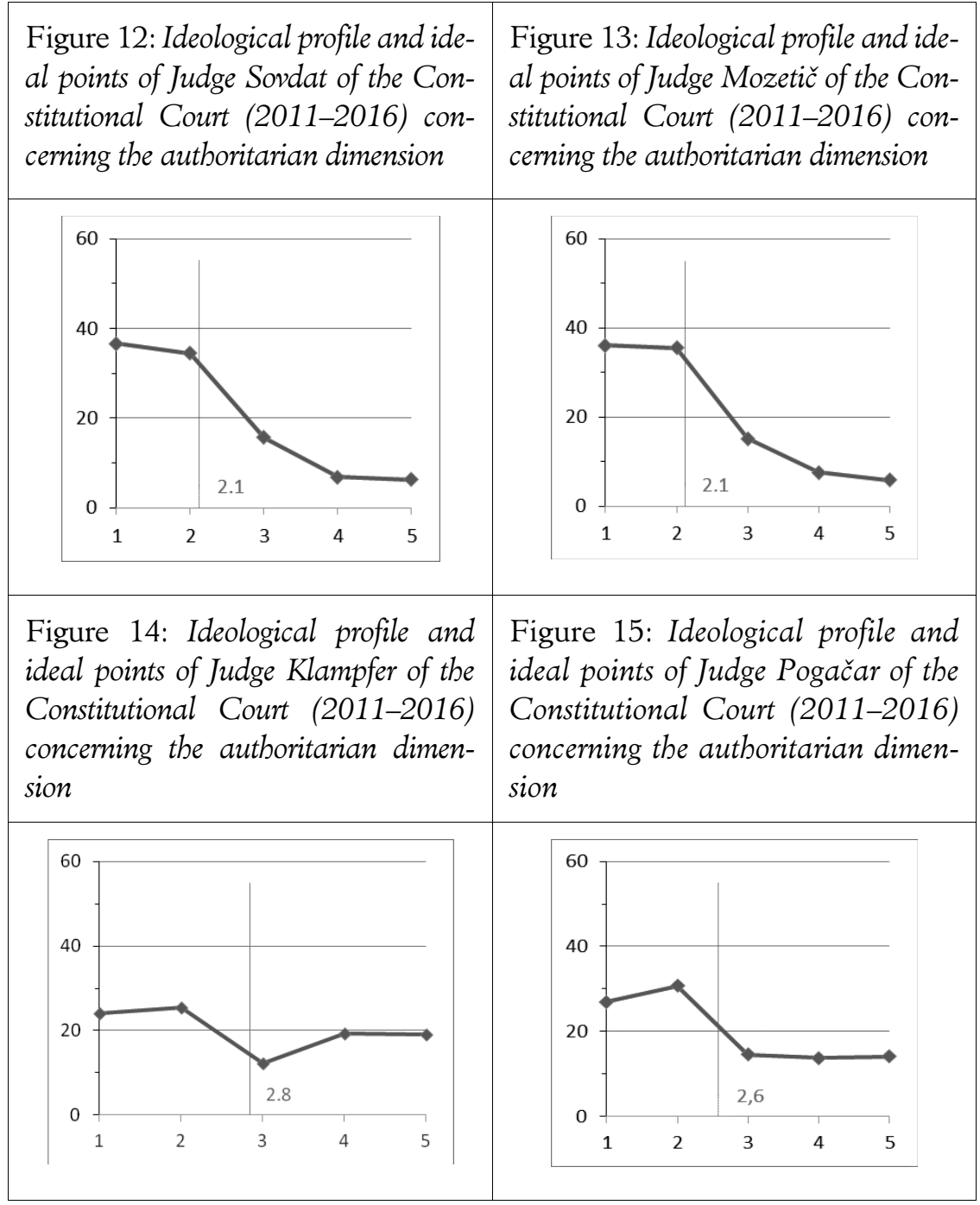

Source: Author. 


\section{Relevance of the Results}

Our research illustrates that all three examined mandates of the Constitutional Court find themselves somewhere in the middle of the authoritarian dimension of judicial ideology. More specifically, the second and third mandate of the Constitutional Court have been located to the left of the centre of possible ideological positions, whereas the first mandate is positioned slightly to the right. Surprisingly, our research points out that the first mandate has been the most authoritarian in the sense that it protected the stability and authority of the newly-formed legal order of democratic and independent Slovenia. The first mandate of the Constitutional Court was occupied with establishing formal standards of the rule of law and dealing with human rights violations of the past (Avbelj \& Letnar Černič, 2020). Its role has been perhaps more difficult as it had to restore or re-establish individual rights and the rule of law after several decades of authoritarian rule.

The second (2002-2006) and third mandates (2011-2016) of the Constitutional Court have been perhaps more favourable to individual rights and therefore slightly less authoritarian than the first. The analysis of the decisions of the second mandate demonstrates that at least some of the judges have been very open to the application of foreign and international jurisprudence through comparative and international legal arguments (ibid). Also, some of the most authoritarian judges are found in the first mandate. Perhaps one of the reasons for their authoritarian judicial ideology can be found in the fact that those judges established the new rule of law standards from the ground up and placed individual rights at the centre of the constitutional order. All in all, our investigation into the authoritarian dimension of judicial ideology at the Slovenian Constitutional Court demonstrates that the ideology was clearly present in its judicial decision-making and that all three mandates found themselves (with slight variations) at the centre of the ideological spectrum; somewhere between the protection of individual rights and the preservation of the authority and stability of the existing legal system.

Our research has generated rich results concerning various aspects of judicial decision-making and the authoritarian dimension of judicial ideology at the Constitutional Court in its three mandates. The results are relevant in various contexts. First, the empirical data demonstrate which mandates and individual judges showed greater preference for individual rights and which judges gave preference to state interests, as well as the differences 
and similarities between them. They allow us to understand more closely how three mandates of the Constitutional Court have decided cases and their relationship between individual rights, political liberalism, state interests and the preservation and stability of the existing legal order.

Measuring and analysing the authoritarian dimension of judicial ideology of the Constitutional Courts contributes to the understanding of how its different mandates have formed and reached decisions. In turn, such analysis assists in augmenting the legitimacy and credibility of its decisions (Avbelj, 2019). It also explains the differences and similarities between different mandates of the Constitutional Court. As a result, it can be discerned how consent and dissent have been formed at the Constitutional Court. In this way, one can compare and analyse an individual judge's ideological position with that of the political parties which elected a particular judge to the position of judge at the Constitutional Court.

Secondly, the results prove that the ideological position has been an influential factor in the decision-making of all three mandates of the Constitutional Court. Almost all examined decisions portray one or more ideological positions with the authoritarian dimension being the most present. The findings have confirmed that the Constitutional Court has been more inclined to favour a discursive approach to law, which rests on the exchange and persuasiveness of different arguments, which are often subject to the ideological positions of judges deriving from their family, private and professional lives and backgrounds (Avbelj, 2019). It shows that the decision-making at the Constitutional Court has only rarely been paved by the objectivist approach to law that submits that judges decide cases objectively and politically neutrally, and the resolution of disputes proceed only by the technical application of a legal norm. It also enables the first insights into the psychological aspects of judicial ideology at the Constitutional Court, especially the relationship between the judges (Epstein, 2016). The presence of judicial ideology reinforces the importance of legal argumentation and the persuasiveness of legal arguments to reach a decision in a particular case. As a result, it calls for better use of the methods of legal argumentation in deciding individual cases.

Thirdly, the ideology is therefore clearly present in judicial-decision making. The scope and nature of judicial-decision making often depends on the nature of the legal norm and legal dispute. When a legal norm is definitive and closed in nature, there will be less scope for the presence of judicial ideology (Avbelj, 2019). In contrast, where legal norms allow for more open interpretation, the space for ideology also increases. Addition- 
ally, the extent of judicial ideology at the Constitutional Court depends on the quality of the legal system. This could explain why the empirical data have shown that the first mandate of the Constitutional Court was a bit more authoritarian than the ensuing two.

Judges of the first mandate spent most of their professional careers in the former authoritarian system, which favoured the authority of the law much more than the rule of law and individual rights. Such a pattern can also be seen in the authoritarian dimension of judicial ideology of the first mandate. In contrast, the second and third mandates were distanced from the former socialist system and more accustomed to the language of the rule of law and human rights, developed by the first mandate. The second and third mandates of the Constitutional Court were able to translate those formal standards to the judicial decision-making in concrete cases. As a result, the authoritarian dimension of the judicial ideology of the second and particularly third mandate were slightly less authoritarian. Therefore, the second and third mandate find themselves to the left of the centre of ideological positions. More research would be needed to examine whether individual judicial decision-making at the Constitutional Court was also influenced by personal family, private, and professional experience (Grossman, 1966; Harris \& Sen, 2019).

Fourthly, examination of the ideological position of all three mandates concerning the authoritarian dimension illustrates how authoritarian a particular mandate was in exercising its judicial mandate for the protection of individual rights and constitutional review. Additionally, the results could be employed in the research of judicial ideology of the current and future mandates of the Constitutional Court, which are also asked to navigate between individual rights and the authority and stability of the legal system. The empirical data illustrate that since its creation, the judges of the Constitutional Court have been very ideological. We noted earlier that "courts and judges need to be aware of and accept the political nature of their actions, which is why they must carefully ensure that they act as publicly as possible and that they judge impartially, independently and fairly in an effort to improve the quality of their judgments. The people on whose behalf they judge will only accept their decisions if they are delivered on the basis of persuasive and in-depth legal arguments and without the presence of actual and potential conflicts of interest. Compelling legal argumentation, in fact, disproves the political conditionality of every judge, since a judgment or voice stands or falls with solid and indepth legal arguments" (Letnar Černič, 22. 9. 2017). The research affirms that most of the mandates of the Constitutional Court have recognized 
such a challenge and have worked towards satisfying those requirements of legal reasoning.

\section{Conclusion}

This article argues that ideology has undoubtedly been a deciding factor in the decision-making of the Slovenian Constitutional Court. The objectivist approach to law, which has been prevalent in recent decades in Slovenia and elsewhere in Central and Eastern Europe, argues that there is no room for the influence of ideology in judicial decision-making. It argues that reaching a decision in a judicial dispute is merely a technical process of applying legal norms to given facts. However, our empirical research has shown that the decision-making at the Slovenian Constitutional Court has been overwhelmingly ideological, which in some cases has been more and in others less visible. All three analysed mandates of the Constitutional Court reached their decisions in most cases concerning constitutional complaints and constitutional review based on three dimensions of their judicial ideology. As a result, this article aimed to examine how much this judicial ideology is present in the case-law of the Constitutional Court by answering the question of how authoritarian it has been in the first three mandates of its existence.

Our research illustrates that all three mandates find themselves more or less in the central ideological positions concerning the authoritarian dimension of judicial ideology, namely somewhere in the middle between protecting individual rights and preserving the authority and stability of the existing system. For this reason, the first three mandates of the Slovenian Constitutional Court cannot be described as authoritarian in their decision-making. Nonetheless, the second and third mandates of the Constitutional Court were slightly more inclined to protect individual rights against the authority of the state and stability of legal orders than the first mandate. The research data illustrate that some judges during those first three mandates of the Constitutional Court were more authoritarian in their judicial decision-making than others.

The recognition that the Constitutional Court has been embedded with judicial ideology is important for its judges in order to reinforce the respect for human dignity, pluralism, and the rule of law. It is now clear that the judges of the Slovenian Constitutional Court do not decide cases like robots and are not ideologically neutral. They are like any other human 
being; products of their family, private, and professional environments, which in almost every case influence their decision-making. Nonetheless, judges are capable of exercising their judicial functions professionally by focusing on strong argumentation and the persuasiveness of legal argumentation. The empirical research has illustrated that reliance on the objectivist perception of the law in the Slovenian domestic legal system has been erroneous. It has often been employed to hide arbitrary abuses of the rule of law and conflicts of interest when exercising judicial tasks. The objective of this article has been to present and analyse empirical results concerning the authoritarian dimension of judicial ideology at the Slovenian Constitutional Court. The results therefore confirm the hypothesis that judges have been overwhelmingly ideological when deciding cases. The Constitutional Court and its judges have been very much present in the social environment of the Slovenian society and its decisions have reflected on their ideology. The presence of judicial ideology at the Constitutional Court calls for even greater emphasis on the discursive approach in its judicial-making. It also advocates for more transparency in the selection procedures for new judges. All in all, discursive, argumentative, and transparent approaches to the law should become commonplace in order to more effectively protect values of human dignity, pluralism, broadmindedness, and the rule of law.

Finally, the data allow ample opportunities for future research. For instance, our research should trigger further analyses on whether the judicial ideology of judges corresponds to ideology that an individual judge portrayed in their scholarship, teaching, and civil society engagement before they were elected to the Constitutional Court. Also, it appears that there is some correlation between the ideological position of individual judges and those of political parties that elected them in the National Assembly to the position of Constitutional Court judges. Additionally, much more detailed and in-depth research is required as to the impact of the legislative and executive branches on the judicial ideology of the Constitutional Court. Moreover, the inter-relationship between ideology at the ordinary courts and the Constitutional Court is another gap, which future research could fill. 


\section{References}

Avbelj, M., (2018a). Contextual analysis of judicial governance in Slovenia. German Law Journal, 19(7), 1902-1930.

Avbelj, M., (2018b). The sociology of (Slovenian) constitutional democracy. Hague Journal on the Rule of Law, 10(3), 35-57.

Avbelj, M. (2019). Pomen sodne ideologije v pravu. [The importance of judicial ideology in law]. Pravnik, 74(7/8), 437-461.

Avbelj, M., \& Šušteršič, J. (2019). Conceptual framework and empirical methodology for measuring multidimensional judicial ideology. DANUBE: Law, Economics and Social Issues Review, 10(2), 129-159.

Avbelj, M., Šušteršič, J., Vatovec, K., Jevšek Pezdir, A., Letnar Černič, J., \& Šušteršič, S. (2018). Pojmovni okvir in empirična metodologija za merjenje večdimenzionalne ideologije na sodiščih. [Conceptual framework and empirical methodology for measuring multidimensional ideology in courts]. Prama praksa: PP, 37(44), II-VIII.

Avbelj, M., \& Letnar Černič, J. (2020). Impact of European institutions on the rule of law and democracy: Slovenia and beyond. Oxford, UK: Hart (Bloomsbury).

Bailey, M. A. (2016). Measuring ideology on the Courts. In R. M. Howard, A. Kirk, \& K. A. Randazzo (Eds.), Routledge handbook of judicial bebaviour (pp. 62-83). New York, USA: Routledge.

Cross F. B., \& Tiller, E. H. (1998). Judicial partisanship and obedience to legal doctrine: Whistleblowing on the Federal Courts of Appeals. The Yale Law Journal, 107(7), 2155-2176.

Epstein, L. (2016). Some thoughts on the study of judicial behaviour. William and Mary Law Review, 57(6), 2017-2073.

Garoupa, N. (2010). Empirical legal studies and constitutional courts. Illinois Law and Economics Research Papers Series, Research Paper No. LE-10-015. Retrieved from: https://papers.ssrn.com/sol3/papers.cfm?abstract_id=1635963.

Grossman, J. (1966). Social backgrounds and judicial decision-making. Harvard Law Review, 79(8), 1551-1564.

Hanretty, C. (2014). The Bulgarian Constitutional Court as an additional legislative chamber. East European Politics and Societies, 28(3), 540-558.

Harris, A. P., \& Sen, M. Sen (2019). Bias and judging. Annual Review of Political Science, 22, 241-259.

Kantorowicz, J. \& Garoupa, N. (2016). An empirical analysis of constitutional review voting in the Polish constitutional tribunal, 2003-2014. Const Polit Econ, 27, 66-92.

Kleinberg, J., Lakkaraju, H., Leskovec, J, Ludwig, J., \& Mullainathan, S. (2018). Human decisions and machine predictions. The Quarterly Journal of Economics, 133(1), 237-293.

Letnar Černič, J., (22.9. 2017) Nepolitično sodstvo? [Non-political judiciary?]. Retrieved from IUS-INFO, https://www.iusinfo.si/medijsko-sredisce/kolumne/204228. 
Letnar Černič, J. (2018a). Impact of the European Court of Human Rights on the rule of law in Central and Eastern Europe. Hague Journal on the Rule of Law, 10(1), 111-137.

Letnar Černič, J. (2018b). The European Court of Human Rights in the States of the Former Yugoslavia. East European Yearbook on Human Rights, 1(1), 32-54.

Letnar Černič, J., Avbelj, M., Novak, M., \& Valentinčič, D. (2018). Reforma demokratične in pravne države $v$ Sloveniji. [Reform of democracy and the rule of law in Slovenia]. Kranj, Slovenia: Nova univerza, Fakulteta za državne in evropske študije.

Letnar Černič, J. (12. 7. 2019). Ideologija na Ustavnem sodišču. [Ideology in the Constitutional Court]. Retrieved from IUS-INFO, https://www.iusinfo.si/ medijsko-sredisce/kolumne/245847.

Letnar Černič, J., (22. 3. 2019) Ustavno sodišče v iskanju identitete?. [The Constitutional Court in search of identity?]. Retrieved from IUS-INFO, https://www. iusinfo.si/medijsko-sredisce/kolumne/239110.

Pócza, K., Dobos, G, \& Gyulai, A. (2019). Dissenting coalitions at the Hungarian Constitutional Court 1990-2018. In M. Belov (Ed.), The role of courts in contemporary legal orders (pp. 359-370). The Hague, Netherlands: Eleven International Publishing.

Pócza, K., Dobos, G., \& Gyulai, A. (2017). How to measure the strength of judicial decisions: A methodological framework. German Law Journal, 18(6), 1557-1586.

Szente, Z., (2016). The political orientation of the members of the Hungarian Constitutional Court between 2010 and 2014. Constitutional Studies, 1(1) 123-149.

Uzelac, A. (2010). Survival of the third legal tradition? Supreme Court Law Review, 49 S.C.L.R. (2d), 377-396.

Zobec, J. (2015). Slovenia: just a glass bead game? In I. Motoc, \& I. Ziemele (Eds.), The impact of the ECHR on democratic change in Central and Eastern Europe: Judicial perspectives (pp. 425-456). Cambridge, UK: Cambridge University Press.

Zobec, J., \& Letnar Černič, J. (2015). The remains of the authoritarian mentality within the Slovene judiciary. In M. Bobek (Ed.), Central European judges under the European influence: The transformative power of the EU revisited (pp. 125-148). Oxford, UK; Portland, USA: Hart Publishing.

\section{Legal sources}

Constitution of the Republic of Slovenia, (Official Gazette of the Republic of Slovenia, št. 33/91-I.

42/97 - UZS68, 66/00 - UZ80, 24/03 - UZ3a, 47, 68, 69/04 - UZ14, 69/04 UZ43, 69/04 - UZ50, 68/06 - UZ121, 140, 143, 47/13 - UZ148, 47/13 UZ90, 97, 99 in 75/16 - UZ70a). 


\section{Judicial decisions}

Constitutional Court of Slovenia, U-I-304/96, 7 November 1996.

Constitutional Court of Slovenia, U-I-246/02, 7 April 2003.

Constitutional Court of Slovenia, Up-584/12, 22 May 2014.

\section{AUTHORITARIAN DIMENSION OF JUDICIAL IDEOLOGY OF THE SLOVENIAN CONSTITUTIONAL COURT}

\section{Summary}

After the democratization and independence of Slovenia, the Constitutional Court has generated the paradigm reform in the Slovenian constitutional system by protecting individual rights against the heritage of the former system. The constitutional judges are not blank slates, but individuals embedded in their private and professional environments. In the past three decades, the Court has delivered several seminal decisions concerning the protection of the rule of law, buman rights, and constitutional democracy. What motivates constitutional judges to protect individual rights in some cases and show preference for the preservation of authority and stability of the existing legal system in others? The article is based on an empirical research measuring the presence of judicial ideology at the Constitutional Court of Slovenia in the selected periods of 19931997, 2002-2006, and 2011-2016 within the first three eight-year mandates. The methodological and theoretical model aims to measure economic, social, and authoritarian dimensions of judicial ideology (three-fold judicial ideology model). The research group has analysed the decisions and separate opinions of the Constitutional Court from selected periods based on bypotheses provided by the model. This article intends to present and analyse the research results concerning the authoritarian dimension of judicial ideology. More specifically, it examines the level of authoritarianism of the Slovenian Constitutional Court in its judicial decision-making during the three mentioned mandates. Through the obtained empirical results, the paper seeks to strengthen fair, impartial, and independent functioning of the Slovenian Constitutional Court and its respective judges.

Keywords: judicial ideology, Slovenian Constitutional Court, the rule of law, constitutional democracy, buman rights 


\title{
AUTORITARNA DIMENZIJA SUDSKE IDEOLOGIJE SLOVENSKOG USTAVNOG SUDA
}

\begin{abstract}
Sažetak
U razdoblju nakon demokratizacije i neovisnosti, Ustarni sud proveo je bitnu promjenu slovenskog ustavnog sustava prema zaštiti pojedinačnih prava, naspram naslijeđa bivšeg sustava. Ustavni suci nisu prazne ploče nego osobe koje žive u svojoj privatnoj i profesionalnoj okolini. U protekla tri desetljeća Sud je donio nekoliko važnih odluka koje se odnose na vladavinu prava, ljudska prava i ustavnu demokraciju. Što je potaklo ustavne suce da u nekim slučajevima zaštite pojedinačna prava, a u drugima preferiraju zaštitu vlasti $i$ stabilnost postojećeg pravnog sustava? Rad se temelji na empirijskom mjerenju sudske ideologije u tri mandata (1993.-1997., 2002.-2006., 2011.-2016.). Metodološki i teorijski model mjeri ekonomsku, socijalnu i autoritarnu dimenziju sudske ideologije (trokomponentni model ideologije). Istraživačka skupina je analizirala odluke $i$ izdvojena mišljenja iz odabranih razdoblja prema odrednicama tog modela. Svrha ovog rada je prezentirati i analizirati dobivene rezultate koji se odnose na autoritarnu dimenziju sudske ideologije, odnosno utvrditi koliko je autoritaran bio slovenski Ustarni sud u donošenju odluka u tri navedena mandata. Kroz to se želi ojačati pošteno, nepristrano i neovisno djelovanje slovenskog Ustavnog suda i njegovih pojedinačnih sudaca.
\end{abstract}

Ključne riječi: sudska ideologija, Ustavni sud Republike Slovenije, vladavina prava, ustavna demokracija, liudska prava 